\title{
THE GLACIAL HISTORY OF THE GREAT LAKES. RECENT PUBLICATIONS.
}

Summary of the Surface Geology of Michigan, by A. C. Lane. Michigan Geological Survey. Anuual Report for 1907.

The Raised Beaches of the Cleveland, Berea, and Euclid sheets of Ohio, by Frank Carney. Vol, V part 4, of the 17th Annual Report of the Ohio State Academy of Science. 1909.

The Abandoned Shore Lines of Eastern Wisconsin, by J. W. Goldthwait. Wisconsin Geological and Natural History Survey. Bulletin No. XVII. 1907.

The Ann Arbor Folio, by Frank Leverett and others. United States Geological Survey Folio No. 155. 1908.

Teachers of physical geography in the secondary schools of the middle west, especially in those states about the Great Lakes find scant material for the class discussion of the former extension of the Great Lakes. The above publications of recent date bring to the geography classes a wealth of material in the glacial history of this region. These are largely detailed studies of the local areas, where the raised beaches are well developed, and these investigations have followed the brief but admirable summary of the glacial history of the Great Lakes by F. B. Taylor and the more extensive monographs on the various ice lobes by Frank Leverett.

In the "Abandoned Shore Lines of Wisconsin," there is an extensive summary of the investigations of the history of the Great Lakes from the time of Col. Whittlesey in Ohio, Bella Hubbard in Michigan, Hall in New York, and Lyll in Ontario. A short summary of the extinct iakes serves as a valuable introduction to the discussion of the conditions in Wisconsin. The most important contribution in this paper is the careful tracing of the beaches along the western shore of Lake Michigan and their relation to the warping or the uplifting of the land. It is shown by spirit leveling that the beach at Washington Island in Green Bay is 70 feet higher than the corresponding beach to the south at Two Rivers, Wis. Since the above results were published Goldthwait, in connection with Taylor, has traced the Algonquin beach along the eastern edge of Lake Michigan and it has been found that this beach at Mackinac Island, Mich., is over 200 feet above the same beach at the southern end of this lake. This gives some conception of the uplifting which has taken place in this region since glacial time, and its effects are seen in the form, the drainage, and the size of the present Iakes.

The "Ann Arbor Folio" contains a clear description of the glacial forms in the vicinity of Ann Arbor and Ypsilanti, Michigan. The abandoned shore lines of this region are clearly shown on an excellent map and their features well described. The evolution of drainage in southern Michigan is well worked out. It is a local study in a region where there exists an unusual combination of inter-lobate moraines, ancient beach lines and Ievel lake plain country.

In the "Summary of the Surface Geology of Michigan" is a elear geological map and a large scale surface map of the state. The latter 
is in sections and could be easily mounted for a wall map which would prove valuable in local geography in any part of the state and to students outside of the state it is of worth to illustrate the looped cliaracter of the moraines and various relations between the glacial deposits and the ancient ice sheet. There is a brief discussion of the various glacial forms which is accompanied by selected examples for illustration, $i$. e., the drumlins from the Traverse Bay region, the esker's between Jackson and Iansing, the kames at Howell, walled lake in Sanilac county, and the beach lines between Ypsilanti and Detroit. The soil, which means much to the life of a region and usually receives a slight in high school geography, is briefly discussed and its economic importance brought to the attention of the reader. The History of the Great Lakes is reviewed in clear language and well illustrated by maps so that it might form a guide for the high school student and teacher. This Summary of the Surface Geology of Michigan deserves a wide distribution in the state, and other state surveys would perform a valuable service if they would issue similar short summaries for the use of the teachers of their respective states.

In the "Raised Beaches of the Euclid, Cleveland, and Berea Sheets of Ohio," there is a discussion of the beaches of northern Ohio which is the classic ground where the investigation of the glacial lake beaches had its origin. The accompanying map of this region is a poor one, but this defect will no doubt be remedied in the forthcoming publications and the style is sucl that it will be easily understood by the high school student. The course traversed by each beach across the region is described in detail and special attention is given to the life relation of these ancient shore lines. The Cuyahoga River, the old delta, and the extinct beaches are considered in relation to their effect upon the growth of Cleveland.

With these publications, along with some of the pioneer works by Taylor, Leverett, and Wright, at the disposal of the teacher there is no reason why a course in physical geography should not be full of interest and of practical value. There is certainly no excuse for a droning over the archaic material when the new possesses so much of the vital.

W. M. GREGORY.

\section{CHILDREN LEARN HOW TO PREVENT CONSUMPTION.}

\section{Country Loses Mrlions Yearly in Wasted Education.}

Over 2,500,000 of the $17,000,000$ school children enrolled in the United States have during the school year just closed, been systematically instructed concerning the dangers of consumption and the methods for its cure and prevention, according to a statement issued to-day by the National Association for the Study and Prevention of Tuberculosis.

Besides the 2,500,000 children thus regularly instructed in their schools, the National Association estimates that fully 1,000,000 more have received instruction at the various tuberculosis exhibits held in all parts of the country or in separate classes and organizations.

A number of investigations conducted in various parts of the world show that a large percentage of the children in the public schools have 